\title{
Bisakah Angklung menjadi Instrumen Psikoedukatif? Studi Eksploratif pada Pemain Angklung
}

\author{
Retno Hanggarani Ninin ${ }^{1}$, Roswita Amelinda ${ }^{2}$ \\ ${ }^{1}$ Universitas Padjadjaran, J1. Raya Bandung-Sumedang Km. 21, Jatinangor, Sumedang \\ ${ }^{2}$ IndoLecture Pramadana Kreasi, Jalan Suryalaya II No.2 Bandung \\ e-mail:rhninin@unpad.ac.id
}

\begin{tabular}{|c|c|}
\hline Abstract/ Abstrak & Keywords/ Kata kunci \\
\hline $\begin{array}{l}\text { Angklung is a unique traditional Sundanese music instrument involving a number } \\
\text { of people to play it to produce a musical appearance. This uniqueness may } \\
\text { indicate that angklung is not only an instrument of art, but also a psychoeducation } \\
\text { instrument. This study explores the experience of angklung players in playing } \\
\text { angklung and proves the use of angklung as a psychoeducation instrument. This } \\
\text { study used explorative qualitative approach on seven angklung players. The } \\
\text { results identify types of angklung player experience: audio-emotional, } \\
\text { interactional (fellow players or coaches), and personal (interest, awareness, } \\
\text { failure). Prerequisites of the use of psychoeducation instruments including the } \\
\text { conversion of the role of the trainer to the educator, identifying specific behaviors } \\
\text { in playing angklung as a simulation of the reality of social interaction, and } \\
\text { providing instructions on how to play angklung optimally based on their parts. } \\
\text { Angklung has psychoeducation potential to develop psychosocial skills } \\
\text { (hablumminannaas) and servitude to God (hablumminnallah). }\end{array}$ & $\begin{array}{l}\text { angklung; } \\
\text { sundanese; } \\
\text { psychoeducation; } \\
\text { psychosocial competence; } \\
\text { religiosity }\end{array}$ \\
\hline $\begin{array}{l}\text { Angklung merupakan alat musik tradisional Sunda dengan keunikan bahwa } \\
\text { diperlukan sejumlah orang untuk memainkannya agar bisa menghasilkan } \\
\text { penampilan musik. Keunikan tersebut memunculkan fitur yang memungkinkan } \\
\text { angklung untuk tidak sekedar menjadi instrumen kesenian, melainkan instrumen } \\
\text { psikoedukasi. Studi ini bertujuan mengeksplorasi pengalaman pemain angklung } \\
\text { dalam memainkan angklung, serta membuktikan bahwa pemanfaatan angklung } \\
\text { sebagai instrumen psikoedukasi dapat dilakukan. Studi dilakukan pada tujuh } \\
\text { pemain angklung aktif dengan pendekatan kualitatif eksploratif. Hasil penelitian } \\
\text { menemukan adanya tiga jenis pengalaman pemain angklung yaitu: audio- } \\
\text { emosional, interaksional (sesama pemain atau pelatih), serta personal } \\
\text { (kepeminatan, kesadaran, kegagalan). Untuk pemanfaatan instrumen psikoedukasi } \\
\text { diperlukan prasyarat yaitu konversi peran pelatih menjadi pendidik, selanjutnya } \\
\text { mengidentifikasi perilaku-perilaku spesifik dalam bermain angklung kolektif } \\
\text { sebagai simulasi realitas interaksi sosial, dan memberikan petunjuk cara terbaik } \\
\text { memainkan angklung sesuai bagian tanggung jawabnya. Instrumen angklung } \\
\text { memiliki potensi psikoedukatif untuk mengembangkan keterampilan psikososial } \\
\text { (hablumminannaas) dan penghambaan kepada Tuhan (hablumminnallah). }\end{array}$ & $\begin{array}{l}\text { angklung; } \\
\text { sunda; } \\
\text { psikoedukasi; } \\
\text { kompetensi psikososial; } \\
\text { religiusitas }\end{array}$ \\
\hline
\end{tabular}

\section{Pendahuluan}

Indonesia adalah negara dengan beragam seni tradisional. Karawitan Sunda, gamelan Jawa, dan tari Saman dari Aceh, merupakan sebagian kesenian tradisional yang ada dan dimainkan oleh sekelompok orang atau secara kolektif. Angklung adalah alat musik etnis Sunda, dengan keunikan berupa satu alat musik hanya memiliki satu not dalam tangga nada. Konsekuensi dari keunikan itu adalah, bahwa untuk menghasilkan sebuah lagu, diperlukan sejumlah orang untuk memainkannya bersama- sama. Dengan kata lain, angklung adalah suatu instrumen musik tradisional yang bersifat kolektif, karena ia hanya bisa menghasilkan suatu performa musik yang utuh jika dimainkan secara bersama-sama oleh sejumlah orang. Jika satu orang pemain memainkan satu nada, maka minimal membutuhkan tujuh orang untuk menghasilkan lagu yang iramanya terdiri dari tujuh tangga nada.

Angklung merupakan suatu kesenian tradisional yang berhasil bertahan dalam perkembangan budaya modern dan menjalan- 
kan fungsi sosialnya melalui penerapan komunikasi multikultur dalam pertunjukan dan mengintegrasikannya dengan budaya kontemporer (Rachmi, 2019). Namun, perkembangan budaya kontemporer juga membawa konsekuensi pada munculnya kebutuhan untuk menjadikan angklung sebagai instrumen musik yang bisa dimainkan oleh semakin sedikit orang (Pradoko \& Priyanto, 2016), atau satu orang (Pradoko, Rusdewanti, \& Fu'adi, 2018), bahkan sudah dibuat instrumen angklung yang hanya oleh satu orang dapat memainkan melodi, harmoni, dan bas sekaligus yang disebut sebagai angklung garbha swara (Pradoko, Diah, \& Silaen, 2017). Transformasi angklung dari instrumen musik kolektif menjadi instrumen musik solo (individual) berdampak pada hilangnya potensi angklung sebagai instrumen musik psikoedukatif, karena potensi tersebut melekat pada unsur kekolektifan dari instrumen angklung tradisional. Potensi fungsi psikoedukatif yang sama dengan yang ada pada seni Reog Kendang di Kabupaten Tulungagung melalui pembagian tugas memainkan kendang (Nugraheni, 2018), serta serupa dengan tari Zapin Tahtul dari Amnutai, Kalimantan Selatan, dengan fungsi pembelajaran norma yang melekat pada syair lagunya (Noviyanti \& Sutiyono, 2017).

Angklung adalah salah satu bentuk kesenian Sunda. Salah satu sejarah yang dikemukakan oleh Azhari (dalam Musthofa, 2018) menyebut angklung sebagai terinspirasi oleh dua kosa kata bahasa Bali yaitu "angk" dan "lung", yang secara berurutan berarti "nada" dan "putus". Nada yang putus artinya adalah nada yang tidak lengkap, dan membutuhkan angklung lain untuk menyambung atau melengkapinya. Sementara riwayat lain menyebutkan bahwa tabung angklung dipersonifikasi sebagai simbol dari seorang manusia (Rosydiana, 2017). Dikatakan bahwa satu angklung yang terdiri dari minimal tiga tabung bambu melambangkan bahwa sebagai individu, manusia tidak bisa hidup sendiri, melainkan perlu melengkapi hidupnya dengan bersosialisasi.
Mengingat bahwa seni dapat dianggap sebagai cara seorang seniman atau penciptanya memahami realitas (Sunarto, 2016), maka angklung mencerminkan pemahaman masyarakat etnis Sunda akan realitas manusia sebagai seseorang yang membutuhkan orang lain untuk menciptakan harmoni dalam kehidupannya, sebagaimana harmoni dalam permainan angklung yang hanya bisa dicapai jika sejumlah angklung dimainkan bersama secara saling melengkapi. Permainan angklung membutuhkan aktivitas kolektif dari sejumlah orang.

Psikologi Sosial memandang kekolektifan tersebut sebagai modal sosial dari suatu bangsa atau masyarakat (Hafiz, 2018). Pada tingkat individu, dalam perspektif Psikologi, karakteristik kekolektifan tersebut dikenal sebagai interdependent construal (Markus \& Kitayama, 2003), yang dicirikan oleh penghayatan individu akan pentingnya keterhubungan (connectedness) dan saling ketergantungan (interdependence) dengan orang lain.

Ketika diaplikasikan pada kegiatan bemain angklung kolektif, maka keterhubungan dan saling ketergantungan antar sesama pemain merupakan unsur utama dalam bermain angklung. Setiap pemain dalam kelompok pemain angklung harus menjalankan tanggung jawabnya untuk memainkan bagiannya, pada waktu dan cara yang tepat, agar harmoni sebuah lagu dapat tercapai.

Kebutuhan akan keterhubungan dan saling ketergantungan antar pemain dalam kegiatan bermain angklung tersebut dapat dikatakan merupakan suatu unsur psikologis, khususnya pada domain psikososial. Sebagai ilmu yang membahas tentang perilaku beserta proses mental yang mendasari munculnya perilaku, maka permainan angklung sebagai suatu bentuk perilaku budaya yang tumbuh dalam budaya Sunda, merupakan cerminan dari proses mental yang terjadi pada masyarakat penganut budaya tersebut. Jika produk budayanya mengandung kebutuhan akan keterhubungan dan saling ketergantungan, maka kebutuhan itu ada dalam proses mental yang terjadi pada individuindividu dimana budaya itu tumbuh. Perspektif Antropologi menyebutnya sebagai karakter 
nasional (Effendi, 2015), yaitu suatu kualitas personal yang sama pada sejumlah orang sebagai akibat dari kesamaan pengalaman tumbuh dalam satu budaya yang sama, dan penelitian Psikologi terdahulu mengkonfirmasi bahwa masyarakat etnis Sunda memiliki ciri kolektif keterhubungan dan saling ketergantungan di tingkat individu (Ninin, 2015).

Sebagai suatu instrumen musik yang mengedepankan pentingnya keterhubungan dan saling ketergantungan antar pemain sebagai syarat wajib untuk menghasilkan suatu lagu yang harmoni, maka lazimnya pemain angklung, terlepas dari apakah pemain tersebut berlatar belakang etnis Sunda atau tidak, adalah individu yang memahami: 1) perlunya tujuan kolektif, 2) pentingnya kehadiran orang lain dalam pencapaian tujuan kolektif, dan 3) kesadaran akan pentingnya menjalankan tanggung jawab individual karena realisasi dari tanggung jawab tersebut berdampak pada pencapaian tujuan bersama.

Ketiga fitur pemain angklung tersebut, secara substansi konsisten dengan unsur-unsur dalam salah satu konsep Psikologi yang dikenal sebagai kecerdasan sosial, yaitu kesadaran sosial yang memungkinkan seseorang memiliki perasaan tertentu tentang orang lain dan melakukan suatu tindakan tertentu berdasarkan kesadaran tersebut (Goleman, 2006). Pada tataran perilaku sejalan dengan yang dinyatakan oleh Smith (2013) sebagai kemampuan mengatur perilaku dengan cara yang sesuai kebutuhan personal dan kebutuhan konteks tempat seseorang berada. Konsep Psikologi yang juga analog dengan fitur pemain angklung tersebut adalah kompetensi sosial, yang didefinisikan sebagai kemampuan untuk secara efektif menciptakan dan mempertahankan dampak sosial positif melalui pengelolaan sumber daya personal dan lingkungan (Arnold \& Muller, 2012).

Suatu perilaku sosial tentu saja bisa dijelaskan tidak hanya dari suatu perspektif, melainkan multiperspektif. Mengingat bahwa penelitian terdahulu tentang karakteristik personal orang Sunda adalah interdependen dan religius (Ninin, 2015), maka muncul pertanyaan di benak penulis tentang sejauhmana fitur pemain angklung tersebut juga bisa dijelaskan melalui perspektif religiusitas Islam sebagai agama yang mewarnai kebudayaan Sunda, yang terlihat dari ritual adat untuk pernikahan, kelahiran bayi, dan kematian. Penelitian tentang seniman Sunda pun membuktikan hal tersebut (Priatama, Supenawinata, \& Hidayat, 2019).

Dalam perspektif religiusitas, ketiga fitur pemain angklung yang disebutkan terdahulu dapat dijelaskan melalui paradigma diri relasional atau relational self (Andersen \& Chen, 2002). Konsep diri relasional muncul dalam teori interpersonal social-cognitive theory yang mengasumsikan bahwa setiap individu memiliki sejumlah penghayatan keaku-an yang masing-masing tumbuh dan berkembang melalui relasinya dengan orang lain sepanjang kehidupannya. Asumsi tersebut sejalan dengan Gergen (dalam Slife \& Richardson, 2010), yang menyatakan bahwa tidak ada diri atau self yang tumbuh secara terisolasi dari lingkungan sosial. Individu "ada" dalam dunia co-constitution, dengan setiap orang adalah produk dari sejumlah relasi.

Seorang pemain angklung idealnya menyadari bahwa ia tidak dapat berperan sebagai pemain angklung tanpa adanya orang lain yang juga menjalankan perannya, antara lain yaitu pemain yang memainkan not-not lain dan pemain yang berperan sebagai conductor. Artinya, kemungkinan seseorang bisa menjadi sesuatu, selalu terhubung dengan kemungkinan orang lain untuk menjadi sesuatu. Dalam perspektif Neuropsikologi, kesadaran keterhubungan ini adalah aspek fundamental yang mendasari kesiapan seseorang untuk terhubung dengan Tuhan (hablumminallah) dan terhubung dengan manusia (hablumminannaas). Peranan musik tradisional Sunda juga sangat banyak dirasakan berpengaruh terhadap kualitas keagamaan dan religiusitas seorang seniman (Jaenudin \& Tahrir, 2019).

Dalam perspektif Islam, terdapat perintah agar manusia menjadi hamba atau abdi Tuhan, melalui mengabdi atau menyembah (worship) Tuhan sebagaimana dalam Alquran surah Adzdzariyat ayat 56, yaitu "Tidaklah Aku 
ciptakan jin dan manusia kecuali untuk menyembah-Ku". Kemudian dalam surah Thaha ayat 14 juga tertera perintah untuk menyembah Tuhan, yaitu “..., maka sembahlah Aku dan dirikanlah salat untuk mengingat Aku”. Perintah untuk menyembah Allah sebagai Tuhan juga terdapat dalam surah Albaqarah ayat 21: "Hai manusia, sembahlah Tuhanтu...”; surah Alanbiyaa' ayat 92: “... maka sembahlah Aku; surah Annajm ayat 62: "Maka bersujudlah kepada Allah dan sembahlah (Dia)"; dan surah $\mathrm{Al}^{\text {'ankabut ayat }}$ 56 pada bagian akhir ayat yaitu “... maka sembahlah Aku saja". Keseluruhan ayat Alquran yang dirujuk tersebut memuat substansi tentang terhubungnya manusia dengan Tuhannya, melalui relasi "yang menyembah-Yang disembah", atau "hambaTuhan".

Penjelasan interaksionalnya adalah, bahwa peran seorang "hamba" selalu terhubung dengan pihak mitranya yaitu yang berperan sebagai "tuan", maka untuk bisa menjadi "hamba", manusia membutuhkan sesuatu yang berperan sebagai "tuan". Dalam ayat-ayat tersebut, peran seseorang sebagai hamba (yang dikuasai, diatur, diperintah), terhubung dengan peran Tuhan sebagai tuan (yang menguasai, yang mengatur, yang memerintah). Dalam hubungan horizontal dengan sesama manusia, seseorang bisa menjadi makmum jika ada yang menjadi imam. Sebaliknya, seorang imam hanya bisa menjadi imam jika ia mempunyai makmum. Demikian juga dalam hubungan guru-murid, suami-istri, orang tua-anak, penjual-pembeli, dan lain-lain. Kemampuan pemain angklung mengadopsi ketiga fitur hipotetis pemain angklung pada domain psikososial yang disebutkan terdahulu, akan menjadi kompetensi psikososial yang juga dapat diaplikasikan ketika ia berada dalam konteks yang menghubungkannya dengan Tuhan (hablumminallah) maupun dalam konteks yang menghubungkannya dengan orang lain (hablumminannaas).

Penulis mengemukakan fitur pemain angklung tersebut sebagai fitur hipotetis karena belum ada bukti empirik yang memvalidasi bahwa benar setiap individu yang menjadi pemain angklung memiliki ketiga fitur tersebut. Penelitian ini dilakukan untuk mengawali upaya mengeksplorasi fitur-fitur psikologis pada level individu yang teraktivasi oleh kegiatan bermain angklung. Upaya tersebut diperlukan karena jika ternyata terbukti bahwa bermain angklung akan mengaktivasi keterampilan psikososial pada domain kognitif, afektif, dan psikomotor, maka artinya kegiatan bermain angklung dapat difungsikan sebagai suatu instrumen psikoedukasi untuk mengembangkan kompetensi psikososial.

Penulis menganggap pengembangan kompetensi psikososial sebagai aktivitas penting, mengingat bahwa keterampilan psikososial ada pada diri seseorang sebagai suatu potensi, dan perlu dikembangkan melalui sosialiasasi oleh agen-agen sosialisasi di masyarakat. Ketika kita menyadari dan dapat membuktikan bahwa budaya Sunda memiliki instrumen yang memiliki potensi untuk menjadi media pengembangan kompetensi psikososial anggota masyarakatnya, maka menjadi tanggung jawab setiap agen sosialisasi untuk memfungsikan media tersebut secara optimal, khususnya untuk menjamin keberlangsungan transfer antar generasi, atas fitur-fitur psikologis yang diharapkan ada pada setiap anggota masyarakatnya. Dalam hal budaya dan masyarakat Sunda, fitur yang dimaksud adalah kesadaran keterhubungan, serta kemampuan menjaga hubungan antara diri dengan Tuhan (memiliki diri religius) dan orang lain (memiliki kompetensi psikososial).

\section{Metode}

Penelitian ini merupakan penelitian kualitatif eksploratif, yang dilakukan untuk mengeksplorasi pengalaman bermain angklung dari sejumlah pemain angklung aktif. Penelitian eksploratif dipilih untuk tujuan membuka ruang yang seluasnya bagi berbagai pengalaman subjek untuk digunakan sebagai data penelitian. Konsisten dengan tujuan tersebut, maka pendekatan analisis yang dapat menunjang tercapainya tujuan tersebut adalah analisis 
tematik, yang memberi fleksibilitas untuk memanfaatkan data apa adanya juga membangun suatu teori (Braun \& Clarke, 2006). Dalam studi kualitatif eksploratif, teori tidak ditetapkan di awal sebagaimana lazim digunakan dalam pendekatan positivistis, melainkan ditetapkan berdasarkan tema yang muncul pada data. Peneliti hanya menetapkan batasan yaitu bahwa datanya adalah pengalaman subjek yang berada dalam domain psikologis dan dalam konteks psikososial.

Proses penelitian diawali dari pengalaman personal dan observasi partisipatif oleh penulis kedua dan library research oleh penulis pertama, lalu dilanjutkan dengan melakukan studi empiris melalui pendekatan kualitatif dengan pengambilan data menggunakan teknik wawancara. Wawancara dilakukan dengan teknik yang dikategorikan oleh Madill (2008) sebagai semi terstruktur (semi-structured) dan berpusat pada tema (theme-centered), dengan pertanyaan awal bertujuan untuk mengeksplorasi pengalaman partisipan dalam bermain angklung. Selanjutnya, data yang bertema psikososial didalami sesuai dengan subtema yang muncul pada masing-masing partisipan, untuk mendapatkan detail yang spesifik tentang aspek-aspek dalam agregat psikososial tersebut, meliputi stimulus yang mencetuskannya, konteks terjadinya, ekspresi perilaku yang ditampilkan, dan efek perilaku tersebut pada diri partisipan dan orang lain.

Data yang diperoleh berbentuk audio, yang kemudian dikonversi ke dalam bentuk verbal dan dianalisis secara kualitatif menggunakan teknik analisis tematik dengan berfokus pada domain psikologis dan tema-tema psikososial. Analisis dilakukan menggunakan perangkat word processing untuk memudahkan peneliti memberikan penanda warna pada setiap tema dan memberikan catatan-catatan yang diperlukan pada naskah verbatim hasil wawancara.

Penjagaan objektivitas analisis, atau kriteria kelayakan dalam riset kualitatif ini dilakukan dengan menggunakan inter-coder agreement, yang ditempuh melalui analisis individual oleh masing-masing dari kedua peneliti, kemudian melakukan pertemuan untuk melakukan komparasi, mendiskusikan, dan menyepakati hasilnya. Perbedaan ontologis, epistemologis, dan tujuan antara qualitative inquiry dengan riset empiris tradisional menyebabkan munculnya kriteria kelayakan yang berbasis pada bukti praktis dan kebermanfaatan studi di masyarakat dibandingkan dengan konsep kelayakan yang dikenal sebagai validitas dan reliabilitas dalam pendekatan kuantitatif (Gergen, 2014). Wertz mengklaim bahwa riset kualitatif memungkinkan peneliti untuk melakukan analisis induktif interpretatif, dan mendefinisikan konstruk ketika hal tersebut dibutuhkan dalam studi yang akan dilakukan, dibandingkan dengan memanfaatkan studi empiris berbasis uji hipotesis yang lebih memfokuskan perhatian pada isu tentang pengukuran dan argumentasi statistik (Wertz, 2014), sebagaimana diperlukan dalam studi ulayat atau studi budaya sebagaimana saat ini.

Hasil penelitian disajikan berdasarkan sekuens kodifikasi pengalaman subjek. Pada setiap kategori pengalaman, disajikan analisis psikologis yang memungkinkan pendefinisian pengalaman tersebut berdasarkan perspektif Psikologi, baik Psikologi Sosial maupun psikologi religiusitas.

\section{Hasil}

Partisipan berjumlah tujuh orang, tiga orang mahasiswa (dua orang perempuan dan seorang laki-laki; usia 24-25 tahun; data berkisar 6.000-13.000 kata per subjek) dan empat orang siswa SMA (perempuan; usia 17 tahun; data kelompok sekitar 7.000 kata), seluruhnya berdomisili di kota Bandung. Pengambilan data dilakukan di kota Bandung, dengan durasi sekitar satu jam untuk wawancara individual dan sekitar dua jam untuk wawancara kelompok.

Berdasarkan data yang diperoleh dari para partisipan, pengalaman subjek pemain angklung dapat dikategorisasikan ke dalam: 1) pengalaman audio-emosional, 2) pengalaman interaksional dengan subpengalaman yaitu pengalaman dengan sesama pemain, dan pengalaman interaksi dengan pelatih, serta 3 ) pengalaman personal dengan subpengalaman 
meliputi kepeminatan, kesadaran, dan kegagalan.

\section{Pengalaman Audio-emosional}

Pengalaman audio-emosional, yaitu suatu pengalaman mendengar stimulus audio yang kemudian terhubung atau berdampak pada aspek emosional. Pengalaman ini dialami oleh seluruh partisipan. Hasil penelitian menunjukkan bahwa mendengarkan suara musik yang dihasilkan dari instrumen angklung menciptakan keadaan emosi yang positif. Keempat subjek SMA mengekspresikannya melalui pernyataan "bermain angklung tidak membuat jadi capek", "membuat capeknya hilang", "membuat enjoy", dan "bisa dinikmati (musiknya)". Sedangkan subjek mahasiswa mendeskripsikannya sebagai "iramanya bisa menghasilkan lagu yang bagus", dan "merasakan nada".

\section{Pengalaman Interaksional sesama Pemain}

Oleh karena irama musik memiliki ketukan yang konstan sementara dalam permainan angklung antara ketukan yang satu dengan ketukan yang lain dimainkan oleh orang yang berbeda, maka muncul kemungkinan bahwa ada bunyi nada yang hilang (jika pemain lupa memainkan bagiannya pada waktunya) atau bunyi nada yang tidak cocok (jika pemain menggetarkan angklung yang dipegangnya pada ketukan yang salah). Terjadinya kedua peristiwa tersebut berdampak pada disharmoni dalam irama lagu yang sedang dimainkan. Dampak pada aspek psikis subjek adalah "kesal kepada teman yang melakukannya", dan "memaklumi karena pernah berada di posisi itu" (melakukan kesalahan).

Tabel 1

Data Partisipan

\begin{tabular}{ccc}
\hline Subjek & $\begin{array}{c}\text { Usia (dalam } \\
\text { tahun) }\end{array}$ & $\begin{array}{c}\text { Bermain } \\
\text { Angklung Sejak }\end{array}$ \\
\hline Mahasiswi & 24 & SMA \\
Mahasiswa & 25 & SMA \\
Mahasiswi & 24 & Awal Kuliah \\
Siswi SMA & 17 & SD (Kelas 3) \\
Siswi SMA & 17 & SD (Kelas 4) \\
Siswi SMA & 17 & SMP (Kelas 3) \\
Siswi SMA & 17 & SMA \\
\hline
\end{tabular}

Pengalaman Interaksional dengan Pelatih

Setiap lagu terdiri dari banyak not, dan jumlah penggunaan satu not dengan not yang lain dalam satu lagu berbeda-beda, ada yang satu not dimainkan puluhan kali dalam satu lagu, ada yang hanya dimainkan beberapa kali. Ketika alat musik terdiri dari hanya satu not, maka situasi tersebut memunculkan dampak berupa ketidaksamaan jumlah tanggung jawab memainkan instrumen antara pemain angklung yang satu dengan pemain yang lain dan memunculkan tantangan pembagian tugas oleh pelatih angklung. Seluruh subjek yang ternyata merupakan pemain angklung yang diandalkan di dalam kelompoknya masing-masing, mengekspresikan "penerimaan" atas keputusan pelatih ketika mereka mendapatkan tanggung jawab untuk memainkan angklung dengan not yang intensitas memainkannya tinggi dalam satu lagu, dan juga menerima ketika mereka diberi tanggung jawab untuk memainkan jumlah angklung lebih dari satu, bahkan hingga mencapai enam, sementara ada pemain lain yang mendapatkan tanggung jawab untuk memainkan hanya dua instrumen angklung.

Para subjek yang mengalami situasi tersebut menyadari bahwa keputusan pelatih didasarkan fakta bahwa mereka jarang melakukan kesalahan dibandingkan dengan pemain lain, dan bahwa keputusan itu ditujukan agar secara keseluruhan hasilnya "baik", sehingga mereka semua memilih untuk memutuskan "menerima" setiap keputusan pelatih. Eisenberg menyebutnya sebagai empathy-related emotions (Eisenberg, Spinrad, \& Knafo-Noam, 2015), yaitu suatu emosi yang didasarkan pada performa perilaku orang lain.

\section{Pengalaman Personal}

Pengalaman personal dalam bermain angklung pada aspek kepeminatan menunjukkan bahwa ketujuh subjek memiliki minat yang kuat untuk menjadi pemain angklung, dengan dasar yang berbeda. Terdapat peminatan yang didasari oleh penilaian bahwa angklung merupakan alat musik yang "unik", "mudah dimainkan karena hanya perlu mengingat kapan not bagiannya dimainkan", "tidak perlu menguasai 
soal chord sebagaimana alat musik lainnya", dan "rame karena memang harus dimainkan secara rame-rame". Poin "mudah dimainkan" dan "tidak harus menguasai chord" mengedepankan isu tentang keyakinan diri akan kesanggupan melakukannya dan berhubungan dengan kesiapan mengemban tanggung jawab. Sedangkan poin "rame" mengekspresikan perhatian terhadap aspek kebersamaan bersama orang lain. Dengan kata lain, angklung memiliki potensi untuk menjadi alat musik yang diminati disebabkan "kemudahan memainkannya" dan "kebersamaan dengan orang lain dalam memainkannya". Bahkan, satu studi membuktikan bahwa bermain angklung merupakan pembelajaran musik yang efektif pada anak usia dini (Putri, 2012).

Pengalaman personal pada aspek kesadaran teridentifikasi berhubungan dengan kesadaran akan kemampuan diri dan orang lain, yang tercermin melalui antara lain penentuan conductor atau orang yang memimpin sekelompok orang bermain angklung. Ketujuh subjek menyadari pentingnya conductor menguasai lagu dan unsur lainnya dalam permainan angklung, sehingga mereka "menerima dengan kesadaran" ketika teman mereka dipilih untuk menjadi conductor dan bukan mereka, serta menunjukkan kesediaan untuk menampilkan "kepatuhan" atau followership. Terdapat fakta bahwa ada sejumlah perilaku ketidakpatuhan dari subjek SMA ketika temannya diminta untuk menjadi conductor, namun hal tersebut terjadi sebagai bentuk perbuatan iseng dan bukan sikap umum mereka dalam hubungan pemain-conductor.

Pengalaman personal kegagalan muncul dalam situasi ketika subjek tidak konsentrasi, gagal mengingat not sehingga menyebabkan kekosongan suara atau suara antar not yang terputus-putus (karena terlambat membunyikan angklung). Dampak yang muncul pada subjek ketika mengalaminya adalah merasa bersalah dan ingin menghafalkan not bagiannya agar tidak mengulangi kembali kesalahan. Ekspresi kegagalan tampaknya merupakan isu yang ringan bagi para subjek, dalam pengertian bahwa mereka mudah mengatasinya, hanya tinggal "berlatih lagi" atau "mengingat lagi lagunya". Semua subjek mengakui bahwa kegagalan tersebut harus diatasi karena berdampak pada terganggunya keseluruhan performa kelompok, namun pada saat yang sama mereka tidak menganggap bahwa hal tersebut memberatkan. Mencermati konteks dimana penjelasan tersebut muncul pada data, tampaknya hal tersebut berhubungan dengan: 1) pengalaman mereka bahwa pemain lain juga pernah mengalaminya, dan 2) cara mengatasinya bisa dijangkau oleh kemampuan atau kapasitas mereka, sejauh mereka bisa melatihnya. Pengalaman kedua tersebut mengindikasikan adanya keyakinan akan kemampuan diri untuk melakukannya (self efficacy), yang berhubungan dengan anggapan mereka bahwa angklung memiliki tingkat kesulitan moderat atau bahkan ringan dan menjadikan angklung sebagai suatu alat musik yang bisa dimainkan oleh semua orang tanpa mempersyaratkan suatu bakat musik tertentu.

Sebagai suatu bentuk keyakinan seseorang akan kemampuan dirinya menyelesaikan suatu tugas, self efficacy menjadi bagian penting penentu keberhasilan seseorang dalam melakukan sesuatu. Bandura (1982) sebagai penggagas konsepnya menyatakan berdasar penelitian empiris yang ia lakukan, bahwa peningkatan self efficacy seseorang berbanding lurus dengan peningkatan keberhasilannya dalam menyelesaikan tugas dan semakin rendah ketergugahan emosi (yang berpeluang menghambat performa penyelesaian tugasnya). Kajian konseptual tentang self efficacy pada masa sekarang pun masih menunjukkan dukungan pada pernyataan tersebut (Rustika, 2012). Pada tataran empiris, penelitian di Indonesia membuktikan bahwa self efficacy dapat meningkatkan emosi positif terhadap tugas (Sunawan, Yani, Kencana, Anna, \& Mulawarman, 2017) serta memengaruhi secara positif kemampuan seseorang untuk mengambil keputusan tentang obyek yang relevan dengan keyakinannya akan kompetensi diri dalam melakukan sesuatu (Prabowo, Yusuf, \& Setyowati, 2019). Oleh karenanya, karakterisktik instrumen angklung dengan tingkat 
kesulitan moderatnya yang memungkinkan hampir setiap orang meyakini bahwa ia akan kompeten melakukannya, membuat angklung menjadi instrumen yang memiliki predisposisi kuat untuk berhasil menjadi alat edukasi bagi setiap orang.

\section{Diskusi}

Hasil riset menunjukkan bahwa keterlibatan para partisipan dalam permainan angklung membawa dampak emosional berupa perasaan positif yang dicirikan oleh kenyamanan secara psikis. Unsur ini dapat berfungsi sebagai penguat alamiah (natural reinforcer) yang memungkinkan seseorang mampu mempertahankan motivasinya untuk bermain angklung. Pelatih yang peka terhadap karakteristik pemain angklung yang dipimpinnya akan mampu memanfaatkan unsur tersebut guna mempertahankan secara jangka panjang keterlibatan para pemain angklung dalam permainan angklung.

Pada subjek SMA, peran pelatih tampaknya menjadi penguat kondisional (conditional reinforcer) para partisipan untuk bermain angklung, karena ia mampu membuat suasana latihan angklung menjadi nyaman bagi mereka. Suatu kenyamanan yang membuat mereka "merindukan" jadwal berlatih angklung dan bersemangat untuk berlatih agar terpilih menjadi tim pemain angklung yang tampil di depan publik. Jika psikoedukasi dapat dilakukan dalam suasana bermain angklung, maka trilogi "pelatih-teman-tampil di depan publik", merupakan prasyarat untuk pemanfaatan angklung sebagai media psikoedukasi. Pelatih berperan sebagai pemberi pesan yang perlu dipelajari oleh penerima pesan, teman sebagai sesama penerima pesan yang bersama-sama akan menjalankannya, dan tampil di depan publik merupakan konteks yang menciptakan dorongan kuat agar penerima pesan menjalankan tindakan dimana semua pesan yang disampaikan dapat dipelajari.

Setelah pemain angklung memiliki dorongan kuat untuk bermain angklung, maka aktivitas "memainkan angklung secara ber- sama" bisa difungsikan ke tahap selanjutnya, yaitu menjadi media pembelajaran untuk mengembangkan kompetensi psikososial, suatu pengembangan yang sejalan dengan paradigma bahwa "perkembangan merupakan suatu proyek biokultural” (Keller, 2017). Secara teknis, prosesnya mengacu pada trilogi wiragawirama-wirasa yang secara turun-temurun sudah dikenal sebagai unsur-unsur dalam seni gerak, yaitu: 1) wiraga, melakukan aktivitas raga/ fisik dengan gerak yang benar. Dalam seni angklung, berarti menggetarkan angklung dengan cara yang benar; 2) wirama, menyelaraskan gerak raga dengan irama yang ada. Dalam konteks bermain angklung, yaitu mencermati irama yang dibentuk oleh panduan conductor dan respon kolektif sesama pemain angklung; dan 3) wirasa, melibatkan rasa atau emosi dalam melakukannya, sehingga muncul ekspresi dari intrapsikis yang sesuai dengan konteksnya, misalnya gembira, syahdu, semangat, dan lain-lain.

Untuk performa angklung sebagai sebuah karya seni, poin pertama dan kedua merupakan media utama yang membangun karyanya, sedangkan poin ketiga adalah media bantu untuk meningkatkan kualitasnya, terutama jika angklung akan ditampilkan sebagai suatu pagelaran karya seni. Sebaliknya, untuk menjadikan angklung sebagai media psikoedukasi, maka poin pertama dan kedua dari trilogi wiraga-wirama-wirasa merupakan media bantu, sedangkan poin ketiga adalah media utamanya.

Guna menjadikan poin ketiga memiliki fungsi psikoedukasi, pelatih perlu mengkonversi perannya dari pelatih menjadi pendidik. Dalam Psikologi Budaya format pendidikan ini dianggap penting, yaitu suatu pendidikan yang mengkombinasikan tradisi ulayat (indigenous traditions) dengan inovasi pedagogik atau pedagogical innovation (Markova \& Jahoda, 2018). Seorang pendidik, memanfaatkan media bantu untuk mempermudah siswa mempelajari pengetahuan yang perlu mereka pelajari. Maka, dalam format ini, ketika bermain angklung akan difungsikan sebagai media untuk membantu mempelajari keterampilan psikososial, maka 
pendidik perlu melakukan minimal dua hal, yaitu mengidentifikasi perilaku-perilaku spesifik dalam bermain angklung kolektif yang merupakan simulasi dari realitas nyata interaksi sosial, dan memberikan petunjuk tentang cara terbaik memainkan angklung sesuai jenis lagu dan jenis angklung (not) yang menjadi tanggung jawabnya, kemudian dijelaskan hasil apa yang bisa dicapai jika tindakan tersebut berhasil dilakukan oleh setiap orang dan dampak apa yang akan terjadi ketika satu orang atau sejumlah orang tidak berhasil melakukannya.

Langkah pertama, yaitu mengidentifikasi aktivitas dalam bermain angklung yang analog dengan situasi interaksi sosial. Sebagai contoh, perilaku patuh pada arahan conductor merupakan simulasi dari kepatuhan pada figur otoritas dalam kelompok sosial; perilaku "mulai menggetarkan angklung dan mengakhirinya" sepanjang sebuah lagu dimainkan, merupakan simulasi dari pentingnya seseorang bertindak sesuai posisi dan perannya dalam kelompok sosial serta sesuai dengan aturan sosial yang berlaku; perilaku kesediaan memainkan jumlah angklung yang lebih banyak dibandingkan dengan pemain lain, dapat dianalogikan dengan pentingnya memaknai keadilan berdasarkan pemahaman akan perbedaan kapasitas atau kemampuan antara orang yang satu dengan orang lain, demi kepentingan bersama. Berfokus hanya pada menghitung perbedaan kontribusi atau tanggung jawab antar orang tanpa menerima perbedaan kemampuan masing-masing orang, akan berdampak destruktif terhadap keadaan psikis dari pelaku yang memaknainya maupun terhadap kepentingan bersama.

Tindakan kedua memiliki pesan utama yaitu bahwa pendidik perlu mendefinisikan pesan tentang adanya tanggung jawab individual yang terhubung dengan tanggung jawab dan performa kelompok, sehingga keberhasilan atau kegagalan setiap orang menjalankan tanggung jawab individualnya dalam situasi tersebut, akan berdampak langsung pada prestasi kerja dari kelompoknya. Dengan mengalami dan memahami situasi sosial dalam konteks bermain angklung tersebut, siswa dapat memiliki referensi atau pedoman tentang tindakan serupa yang perlu dilakukannya dalam interaksi sosial nyata yang analog dengan sub-subperilaku bermain angklung sebagaimana dijelaskan.

Peristiwa "kegagalan melakukan hal yang benar" atau "kesalahan memainkan secara tepat" dalam latihan bermain angklung, merupakan waktu yang tepat untuk menyampaikan pesan psikoedukatif. Selain peristiwa kegagalan dan kesalahan, keberhasilan juga merupakan peristiwa yang tepat untuk menyampaikan pesan psikoedukatif, melalui apresiasi secara konstruktif terhadap pengetahuan dan keterampilan psikososial yang ingin diajarkan.

Dalam hal fungsi religius atau spiritual, diketahui bahwa angklung diciptakan sebagai alat musik ritual (Budi, Soedarsono, \& Narawati, 2014). Jika pun angklung ketika dimainkan oleh siswa di sekolah saat ini tidak lagi memenuhi fungsi spiritual yang dikehendaki di awal penciptaan alat musik tersebut, namun melalui pembiasaan memainkannya disertai dengan edukasi yang relevan sehingga dapat mengaktivasi sense of wiraga, wirama, dan wirasa, maka angklung masih dapat mengemban fungsi spiritualnya.

Telah dijelaskan terdahulu bahwa memainkan angklung membiasakan pemainnya untuk bertindak dengan mencermati konteks tempat ia berada, mempertimbangkan posisi dan peran diri yang terhubung dengan orang lain, serta memahami pentingnya tunduk pada pimpinan kelompok yang benar dalam menjalankan kepemimpinannya. Untuk mengedukasi tentang sikap dan tindakan yang benar dalam hubungan interaksional hamba-Tuhan, maka cara edukasi untuk keterampilan psikososial yang telah dijelaskan dapat dilakukan, dengan mengganti mitra relasinya dari conductor menjadi Tuhan. Alquran surah Almu'min ayat 60, menjamin bahwa Allah memperkenankan doa seseorang yang berdoa kepada-Nya, dan pada surah Asysyuura ayat 26, Allah memperkenankan doa orang yang beriman dan melakukan perbuatan baik atau disebut sebagai amal saleh (Depag, 1984). 
Pasangan kedua ayat tersebut menyatakan bahwa Tuhan akan memberi pada mereka yang meminta kepada-Nya, dan bahwa syarat agar permintaan tersebut diwujudkan oleh Tuhan adalah bahwa pemintanya harus beriman dan melakukan amal saleh. Penelitian terdahulu tentang hubungan hamba dengan Tuhan menempatkan hubungan tersebut sebagai satu dimensi dari konsep diri religius (Ninin, Iskandar, Sumintardja, \& Siswadi, 2018). Artinya, semakin seseorang memiliki predisposisi untuk mematuhi ketentuan agama agar ia menyembah Tuhan, maka semakin religius dirinya (inner self). Hasil penelitian tersebut, juga mendukung atau memverifikasi pengertian kedua ayat Alquran di atas, yaitu bahwa kepatuhan seorang individu pada Tuhannya akan berdampak pada kesejahteraan psikisnya.

Inti dari edukasi psikoreligius yang bisa dilakukan dalam konteks bermain angklung adalah menekankan pentingnya followership atau kepatuhan. Melalui bermain angklung, ada dua mekanisme kerja yang bisa memberi kontribusi bagi munculnya kesediaan sukarela untuk patuh (willingness obedience), yaitu melalui: 1) mekanisme kerja sistem saraf, dan 2) mekanisme kerja sistem kesadaran. Pada tingkat saraf, cara kerjanya perlu dibentuk melalui pembiasaan untuk patuh sedemikian rupa sehingga terbangun jalur persarafan "kepatuhan". Jika jalur ini sudah terbentuk, maka "kepatuhan" menjadi suatu mekanisme kerja saraf yang cepat muncul ketika situasi yang dihadapi seseorang mengundang munculnya tindakan patuh tersebut. Analoginya seperti refleks menghindar yang dilakukan oleh atlet bela diri ketika menghadapi ancaman, yang terbentuk sebagai hasil dari pembiasaan melalui latihan.

Sistem kerja kesadaran untuk "patuh" bisa dibentuk melalui pemberian pengertian tentang alasan perlunya melakukan tindakan patuh sekaligus alasan pentingnya menghindari tindakan "tidak patuh". Melalui mekanisme ini, kepatuhan terjadi bukan karena pembiasaan untuk patuh, melainkan pembiasaan untuk mengaplikasikan proses berpikir ketika ada "undangan untuk patuh". Melatih seseorang untuk mengembangkan logika rasional atas perlunya "patuh" dan pentingnya menghindari "tidak patuh" akan memungkinkan seseorang untuk memiliki motivasi berbasis rasional atas kepatuhannya. Motivasi berbasis rasional atas kepatuhan, adalah predisposisi yang kuat untuk membangun karakter kehambaan (worshipness) kepada Tuhan. Motivasi kepatuhan jenis ini dikatakan kuat karena membentuk willingness obedience, yaitu kepatuhan yang didasari oleh kesadaran bahwa itu adalah pilihan terbaik yang perlu dilakukan oleh seseorang. Kepatuhan jenis ini lebih menetap dalam jangka panjang, dibandingkan dengan kepatuhan yang bersumber dari pembiasaan tanpa disertai pengertian. Menempuh kedua mekanisme bersama-sama akan menghasilkan akumulasi motif yang kuat akan kepatuhan.

\section{Simpulan}

Melaksanakan tradisi karena menyadari manfaatnya, memunculkan transferability dan kualitas dampak yang lebih kuat pada masyarakat, dibandingkan dengan melaksanakan tradisi hanya karena tradisi. Berdasarkan diskusi terdahulu tentang potensi yang tersedia pada instrumen dan kegiatan bermain angklung untuk mengembangkan karakter positif pada domain sosial dan religius, maka merupakan langkah yang sangat berguna untuk: 1) mempelajari fitur-fitur angklung secara sistematis dan ilmiah, 2) menyadari pentingnya melekatkan peran pendidik pada pelatih angklung, dan 3) menyeimbangkan fokus bermain angklung antara pencapaian keterampilan teknis bermain angklung untuk menghasilkan karya seni pagelaran musik angklung, dengan pencapaian pengetahuan religius dan psikososial untuk menghasilkan karakter yang kompeten dalam interaksi sosial dan penghambaan kepada Tuhan.

\section{Referensi}

Andersen, S. M., \& Chen, S. (2002). The relational self: An interpersonal socialcognitive theory. Psychological Review, 109(4), 619-645. 
Arnold, K. H., \& Muller, C. L. (2012). Assessment and development of social competence: Introduction to the special issue. Journal for educational research online, 4(1), 7-19.

Bandura, A. (1982). Self-efficacy mechanism in human agency. American Psychologist, $37(2), 122-147$

Braun, V., \& Clarke, V. (2006). Using thematic analysis in psychology. Qualitative Research in Psychology, 3, 77-101.

Budi, D. S., Soedarsono, H. T., \& Narawati, T. (2014). Angklung dogdog lojor pada upacara seren taun. Resital, 15(2), 139151.

Depag. (1984). Al Qur'an dan terjemahnya. Jakarta: Departemen Agama Republik Indonesia.

Effendi, N. (2015). Pemahaman dan pembentukan karakter masyarakat: Realitas dan pandangan antropologi. TINGKAP: Interdisciplinary journal of social sciences and social studies, 11(2), 175-185.

Eisenberg, N., Spinrad, T. L., \& Knafo-Noam, A. (2015). Prosocial development. Dalam W. Damon, Handbook of child psychology and developmental science (7th ed., pp. 610-656). Wiley Online Library.

Gergen, K. J. (2014). Pursuing excellence in qualitative inquiry. Qualitative Psychology, I(1), 49-60.

Goleman, D. (2006). Social intelligence: The new science of human relationship (1st ed.). New York, CA, United States of America: Bantam Dell: A division of Random House, Inc.

Hafiz, S. E. (2018). Pendahuluan. Dalam A. Pitaloka, Z. Abidin, \& N. M. Milla, Psikologi sosial: Pengantar dalam teori dan penelitian (pp. 1-19). Jakarta: Penerbit Salemba Humanika.

Jaenudin, U., \& Tahrir, T. (2019). Studi religiusitas, budaya Sunda, dan perilaku moral pada masyarakat Kabupaten Bandung. Jurnal Psikologi Islam dan Budaya, 2(1), 1-8. doi.org/10.15575/jpib.v2i1.3445

Keller, H. (2017). Culture and development - A systematic relationship. Perspective on Psychological Science, 12(5), 833-840.

Madill, A., \& Gough, B. (2008). Qualitative research and its place in psychological science. Psychological Methods, 13(3), 254-271.
Markova, I., \& Jahoda, A. (2018). Across culture, mind and history. Culture \& Psychology, 24(3), 265-281.

Markus, H., \& Kitayama, S. (2003). Culture and the self. Implication for cognition, emotion, and motivation. Dalam M. A. Hogg, Social Psychology (Vol. IV). London: SAGE Publications.

Musthofa, B. M. (2018). Transformasi angklung Sunda dan dampaknya bagi masyarakat: Studi kasus kreativitas angklung di Saung Angklung Udjo. Seminar Nasional Teknologi Terapan berbasis Kearifan Lokal (SNT2BKL). 1, pp. 546-554. Kendari: Program Pendidikan Vokasi Universitas Halu Oleo.

Ninin, R. H. (2015). The self of Sundanese ethnic: Interdependent construal and religious self. Asian Social Science, 11(16), 1-8.

Ninin, R. H., Iskandar, Tb. Z., Sumintardja, E. N., \& Siswadi, A. G. P. (2018). Diri religius: Suatu model konseptual tentang diri (Religious self: A conceptual model of self). Journal of Psychological Science and Profesion, 2(1), 114-126.

Noviyanti, S. R., \& Sutiyono. (2017). Bentuk, perubahan fungsi, dan nilai-nilai edukatif pada musik tari Japin Tahtul di Amuntai. Imaji: Jurnal Seni dan Pendidikan Seni, 15(1), 1-8.

Nugraheni, W. (2018). Penanaman nilai-nilai moral melalui kesenian Reog Kendang terhadap pelajar di Kabupaten Tulungagung. Imaji: Jurnal Seni dan Pendidikan Seni, 16(2), 162-171.

Prabowo, W., Yusuf, M., \& Setyowati, R. (2019). Pengambilan keputusan menentukan jurusan kuliah ditinjau dari student self efficacy dan persepsi terhadap harapan orang tua. Jurnal Psikologi Pendidikan \& Konseling: Jurnal Kajian Psikologi Pendidikan dan Bimbingan Konseling, 5(1), 42-48.

Pradoko, S., \& Priyanto, W. P. (2016). Rancang bangun musik angklung model SATB, dasar aransemen model orchestra. Imaji: Jurnal Seni dan Pendidikan Seni, 14(1), 90-97.

Pradoko, S., Diah, F. X., \& Silaen, H. (2017). Rancang bangun musik angklung model electone organ perpaduan kombinasi bas, harmoni, dan melodi. Imaji: Jurnal Seni dan Pendidikan Seni, 15(1), 1-8. 
Pradoko, S., Rusdewanti, P. P., \& Fu'adi. (2018). Angklung piano dengan penggerak motor elektrik. Imaji: Jurnal Seni dan Pendidikan Seni, 16(2), 118-127.

Priatama, R. P., Supenawinata, A., \& Hidayat, I. N. (2019). Makna hidup dibalik seni tradisional: Studi fenomenologi kebermaknaan hidup seniman Sunda. Jurnal Psikologi Islam dan Budaya, 2(1), 43-64.

Putri, D. R. (2012). Pembelajaran angklung menggunakan metode belajar sambil bermain. Harmonia: Journal of Arts Research and Education, 12(2), 116-124.

Rachmi, F. N. (2019). Implementasi komunikasi budaya kontemporer pada experiential marketing saung angklung Udjo. Dalam M. F. Juddi, U. L. Khadijah, R. K. Anwar, \& A. Rusmana (Eds.), Komunikasi budaya dan dokumentasi kontemporer (1 ed., pp. 152-158). Bandung, Jawa Barat, Indonesia: Unpad Press.

Rosydiana, E. (2017). Meningkatkan kecerdasan musik melalui permainan angklung di PAUD Aulia. Yaa Bunayya: Jurnal Pendidikan Anak Usia Dini, 1(2), 53-64.
Rustika, I. (2012). Efikasi diri: Tinjauan teori Albert Bandura. Buletin Psikologi, 20(1-2), 18-25.

Slife, B. D., \& Richardson, F. C. (2010). Review of relational being: Beyond self and community. The Journal of Social Psychology, 150(2), 226-230.

Smith, P. B. (2013). Through a glass darkly: Viewing the social contexts of our behavior. Asian Journal of Social Psychology, 16, 19-21.

Sunarto. (2016). Filsafat seni nusantara. Imaji: Jurnal Seni dan Pendidikan Seni, 14(1), 81-89.

Sunawan, Yani, S. Y., Kencana, T. I., Anna, C. T., \& Mulawarman, S. A. (2017). Dampak efikasi diri terhadap beban kognitif dalam pembelajaran matematika dengan emosi akademik sebagai mediator. Jurnal Psikologi, 44(1), 28-38.

Wertz, F. J. (2014). Qualitative inquiry in the history of psychology. Qualitative Psychology, 1(1), 4-16. 